\title{
Електронно-мікроскопічне дослідження слизової оболонки фундального відділу шлунка під час дії меланіну на тлі хронічної гіпергастринемії
}

Проведено ультраструктурне дослідження слизової оболонки фундального відділу шлунка щурів за тривалої гіпергастринемії та під час дії пігменту меланіну. Показано, що при гіпергастринемії в усіх шарах слизової оболонки шлунка відбуваються зміни, які свідчать про ії малігнізацію. Уведення меланіну нівелює трофічну дію надлишкового гастрину на епітеліоцити слизової оболонки шлунка щурів.

Ключові слова: гіпергастринемія, слизова оболонка шлунка, малігнізація, меланін.

Постановка наукової проблеми та її значення. На сьогодні онкологічні захворювання - друга провідна причина смертності людей після хвороб серця. В Україні рак шлунка та кишечнику належать найбільш розповсюджених онкологічних захворювань: щорічно реєструють близько 8 тис. нових хворих, більшість із них помирає протягом двох років від рецидивів і метастазів [5]. Тому пошук ефективних речовин, які попереджують канцерогенез шлунково-кишкового тракту, залишається актуальним.

Аналіз досліджень цієї проблеми. Аналіз літератури засвідчив, що перспективними протипухлинними препаратами можуть бути фенольні сполуки, яким приділяють велику увагу оскільки вони належать до адаптогенів природного походження $[11,16,18,21]$. Відомо, що до поліфенольних сполук належать пігменти різного генезу. Проведені раніше дослідження підтвердили цитопротекторну дію меланіну, одержаного з чорнильних сумок морських тварин Ommastrephes bartrami Lesuel [17], березового гриба чаги [15], листя зеленого чаю [13, 16] й винограду [3].

Звернемо увагу на меланін, продуцентом якого $\epsilon$ мікроорганізми зі скель острова Галіндез (Українська антарктична експедиція «Академік Вернадський»), які розміщені в ділянці озонової діри зоні надмірної сонячної активності. Меланін, що виробляється цими мікроорганізмами, захищає їх від надмірного опромінення. У зв'язку з цим ми припустили, що меланін такого походження повинен бути більш сильним радіопротектором, антиоксидантом та протипухлинним засобом, порівняно 3 меланінами іншого походження.

Визначити протипухлинну та протизапальну дію меланіну вирішено на моделі гіпергастринемії [9]. Раніше нами показано, що надмірний рівень гастрину в шлунку чинить трофічну дію на слизову оболонку шлунка й призводить до метапластичних змін у слизовій оболонці [2, 7].

Мета роботи - дослідження змін в усіх типах клітин слизової оболонки фундального відділу шлунка щурів, викликаних гіпергастринемією та під час дії природного пігменту меланіну на електронно-мікроскопічному рівні.

Матеріали та методи досліджень. Дослідження для визначення змін в ультраструктурі клітин слизової оболонки проводили на 30 самцях щурів п'ятимісячного віку. Усіх їх утримували разом в умовах віварію на стандартному раціоні з вільним доступом до комбікорму та води при температурі приміщення $+25^{\circ} \mathrm{C}$. Досліди на тваринах проводили відповідно до закону України від 21.02.2006 № 3447-IV «Про захист тварин від жорстокого поводження» та згідно 3 етичними нормами й правилами роботи з лабораторними тваринами $[1,4,6]$.

Перша група тварин $(\mathrm{n}=10)$ у ході експерименту отримувала хронічні ін'єкції препарату Омез® виробництва «Д-р Редді'с Лабораториз Лтд.» (Індія), діюча речовина якого - омепразол, що є інгібітором $\mathrm{H}^{+}-\mathrm{K}^{+}$-АТФази, ключового ферменту апікальної мембрани парієтальних клітин шлунка, який бере участь у секреції соляної кислоти. Унаслідок дії омепразолу виникає гіпосекреція соляної кислоти, яка веде до гіперсекреції гастрину G-клітинами антрального відділу шлунка. Препарат розчиняли у 0,25 мл ізотонічного $(0,9 \%)$ розчину $\mathrm{NaCl}$ та вводили щурам у дозі 14 мг/кг (в. о.). Піддослідні щури отримували одну ін'єкцію на добу протягом 28 діб.

(С Вороніна О., Берегова Т., Дзержинський М., 2016 
Друга група тварин (n=10) отримувала меланін, який є продуктом життєдіяльності чорних дріжджів Nadsoniella nigra var. Меланін уводили перорально одночасно з омепразолом у дозі 5 мг/кг, розчиненого в 0,5 мл фізіологічного розчину протягом 28 діб.

Контрольна група (n=10) - щурі, які одержували ін'єкції 0,25 мл ізотонічного розчину $\mathrm{NaCl}$ протягом 28 діб.

Після розтину щурів частину слизової оболонки фундального відділу фіксували у $2,5 \%$ розчині глютарового альдегіду. Після заливки матеріалу в смолу за допомогою ультрамікротома UltraCut-R виготовляли ультратонкі зрізи завтовшки 70-80 нм, контрастували у водних 2,5 \% розчинах уранілацетату та цитрату свинцю й аналізували за допомогою трансмісійного електронного мікроскопа ПЕМ-У (ВАТ «Selmi», Україна) при робочому збільшенні х4000-х25000.

Виклад основного матеріалу й обгрунтування отриманих результатів дослідження. У результаті електронно-мікроскопічного дослідження слизової оболонки фундального відділу шлунка контрольних щурів виявлено два основні типи клітин - екзо- та ендокринні. Серед екзокринних клітин можна чітко розрізнити головні, парієтальні й слизові.

Головні клітини містили округле ядро з великою кількістю еухроматину та пристінковим гетерохроматином, добре розвинений білок-синтетичний апарат - гранулярну ендоплазматичну сітку (ЕПС), апарат Гольджі (АГ), а також велику кількість секреторних гранул біля плазмолеми в апікальній частині клітини. Досить розвинений енергетичний апарат клітини: по всій клітині розміщені круглясті та овальні мітохондрії з чіткими трубчастими кристами. На апікальній поверхні клітини траплялися короткі мікроворсинки.

Парієтальні клітини містили велику кількість внутрішньоклітинних секреторних канальців і мікроворсинок, що виступали в їх просвіт. У цих клітинах світле округле ядро. Також у них помітні розвинена гладенька ЕПС й АГ та витягнутої форми мітохондрії з трубчастими кристами (рис.1А).

Слизові клітини мали циліндричну форму, на апікальній поверхні мали мікроворсинки. Ядра містили компактний хроматин і містились у базальній частині клітини. У цитоплазмі помітний розвинений АГ, гладенька ЕПС, мітохондрії. В апікальній частині клітин містилися гранули секрету (рис.1Б).

Ендокринні клітини мали неправильну форму, невелике ядро, розміщене ближче до апікального полюса клітини, та велику кількість секреторних пухирців, що в центральній і базальній частинах клітини. Між усіма клітинами були добре помітні міжклітинні контакти, наприклад щільні контакти й десмосоми.
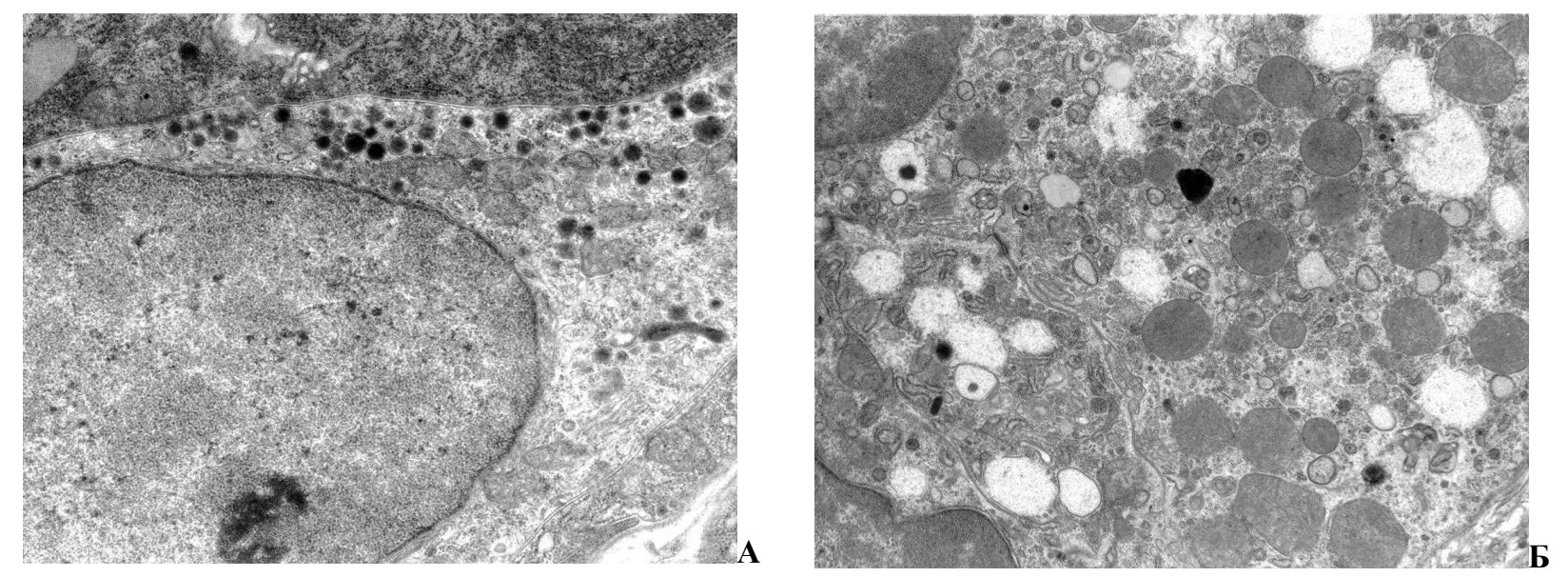

Рис. 1. Електронограма слизової оболонки шлунка контрольної групи щурів. А: 36 Х 9600; Б: 36 Х 9600

При тривалому введенні омепразолу ультраструктурне дослідження засвідчило, що зміни відбуваються в усіх шарах слизової оболонки шлунка (епітелії, власній та м’язовій пластинках). Досить часто у фундальних залозах клітини втрачали свою специфічність, ставали однотиповими, серед них важко було розрізнити окремі різновиди клітин. У них зменшена кількість органелл або взагалі їх не простежено. У цитоплазмі епітеліоцитів накопичувалися продукти аномального обміну речовин, унаслідок чого клітини, набували темного, електронно-ущільненого вигляду. 
У цитоплазмі таких клітин значно зменшена кількість органел, а переважали кератогіалінові гранули та тонофіламенти. Деякі з цих клітин зберігали контакти між собою, але більшість із них утрачала їх, відокремлювалась одна від одної, утворюючи на поверхні мікровирости (рис. 2А). Така будова та розміщення клітин нагадували остистий шар епідермісу. Про те, що в слизовій оболонці шлунка відбувалося перетворення епітелію в багатошаровий плоский зроговілий, свідчила й наявність клітин із нагромадженням гранул кератогіаліну як у цитоплазмі, так і в ядрі, що характерно для кератиноцитів зернистого шару. Останнім і найбільш демонстративним підтвердженням зроговівання епітелію шлунка була присутність блискучого й рогового шарів. У рогових лусочках нагромаджуються, як і в шкірі, пухирці газу. Подекуди поруч з епітеліоцитами та в них спостерігали мікроорганізми, у тому числі й H. pilory (рис. 2Б).

Кровоносні судини мали розширений просвіт, який здебільшого заповнений форменими елементами крові. Цитоплазма ендотеліоцитів, зазвичай, електронно-щільна - i тому важко розрізнити окремі органели.

У м'язовій пластинці спостерігали чергування гладких міоцитів із помірною електронною щільностю, заповнених переважно фібрилярними структурами та незначною кількістю органел, із темними міоцитами, де не можливо виділити ні фібрили, ні органели.

Отже, під впливом омепразолу у тварин виникла метаплазія епітелію слизової оболонки шлунка за стравохідним типом. Слизова оболонка таких тварин не формувала характерні шлункові залози, епітелій був сформований багатьма шарами епітеліоцитів, які не мали ознак клітин слизової оболонки шлунка. Епітеліальні клітини з'єднані десмосомальними контактами, які містили тонофіламенти, характерні для остистого шару епідермісу. Простежено окремі ділянки зроговілого епітелію, відкладання гранул кератогіаліну в цитоплазмі та ядрі кератоцитів. Як відомо, омепразол блокує роботу Н/К-насоса, гальмуючи тим самим базальну й стимульовану секрецію соляної кислоти парієтальними клітинами, що, напевне, є рушійним фактором у патогенезі метаплазії слизової оболонки шлунка [8]. За тривалого використання препарату парієтальні клітини втрачають властиві їм канальці, на мембранах яких розміщуються водневі насоси, редукується їх біосинтетичний апарат, відзначається гіпоплазія мітохондрій та зменшення вмісту крист у них, клітини втрачають морфологічні ознаки власної диференціації. Оскільки, згідно з даними літератури, парієтальні клітини відіграють вирішальну роль у механізмах диференціації шийкових клітин у головні, то головні клітини також утрачають характерні ознаки: у них зменшується вміст гранул зимогену, редукувалися канальці АГ та гранулярної ЕПС [19]. Значних змін зазнавали й мукоцити, у яких різко знижений уміст гранул із муцином, редукований біосинтетичний апарат. Але найбільших змін зазнавали ендокриноцити - у їхній цитоплазмі були відсутні ознаки їх диференціювання - секреторні гранули, органели. Отже, у процес метапластичного переродження включено всі типи клітин шлункового епітелію.

Очевидно, наслідком такого переродження епітелію шлунка можуть бути причиною порушення всіх його функцій: розщеплення білків, усмоктування простих поживних речовин та води [14].

Крім того, на поверхні епітелію експериментальної групи тварин спостерігали скупчення мікроорганізмів. Відсутність властивого для просвіту шлунка кислого середовища сприяе появі та розвитку в ньому патогенної мікрофлори, що може спричинити розвиток запальних змін у шлунково-кишковому тракті.

Знижена кислотність у шлунку експериментальних тварин стимулює синтез і секрецію гастрину G-клітинами пілоричної частини шлунка за механізмом зворотного зв'язку, що призводить до гіпергастринемії [12]. Гастрин, зв'язуючись із власними гастриновими та холецистокініновими рецепторами на мембранах епітеліоцитів шлунка, стимулює їх проліферацію й гальмує апоптичний шлях загибелі цих клітин. Ознаками активної проліферації епітеліальних клітин можна вважати крупні ядра 3 численними інвагінаціями каріолеми, у яких переважають еухроматин, великі активні ядерця 3 більшою чисельністю глобулярного компонента. Такі зміни $є$ проявами атипії й характерні для пухлинних клітин. Очевидно, у цьому випадку метаплазія - це наслідок взаємодії двох процесів (порушення типового диференціювання клітин, з одного боку, та активації проліферативних процесів на фоні порушення апоптозу - з іншого). Як відомо, будь-яка метаплазія епітеліальної тканини є облігатним передпухлинним станом. Тобто виявлені зміни в епітелії шлунка можна вважати одним 3 етапів канцерогенезу. 

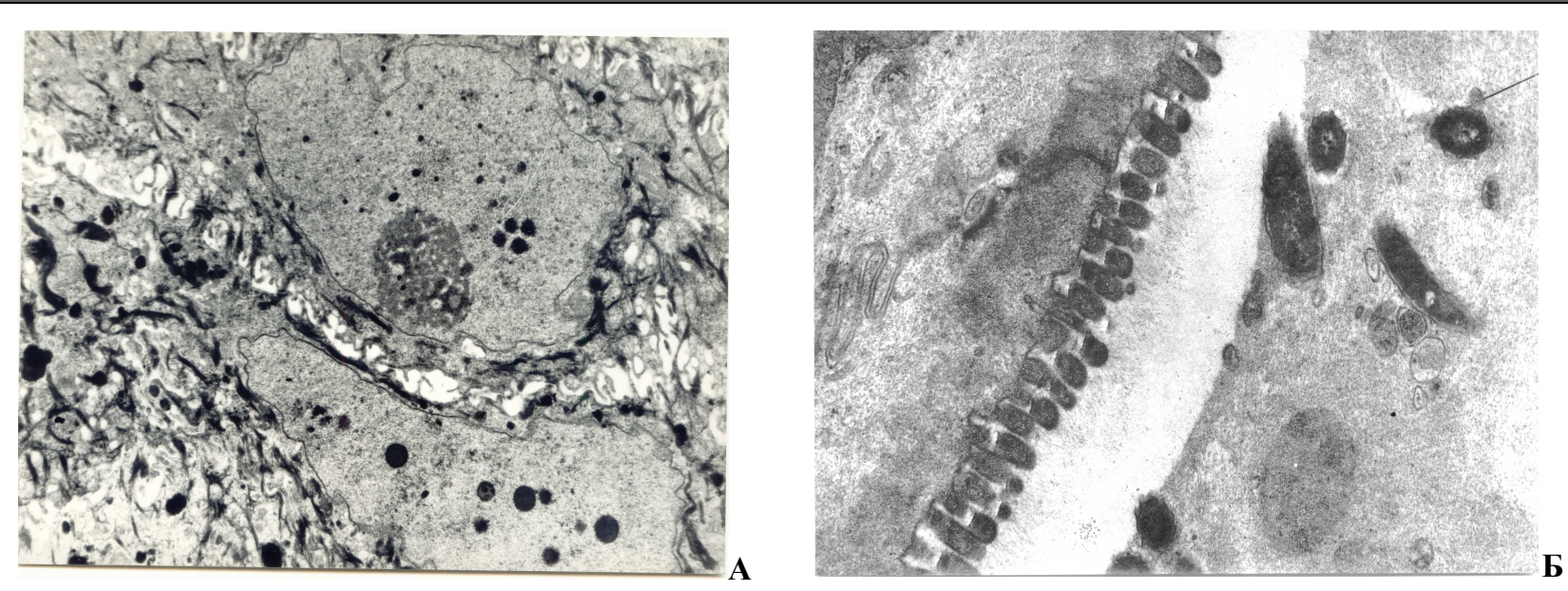

Рис. 2. Електронограма слизової оболонки шлунка після 28-денного введення омепразолу. A: 36 Х9600, Б: 9600

Уведення щурам меланіну на фоні омепразолового ураження попереджало розвиток ультраструктурних змін у слизовій оболонці шлунка, які характерні під час дії омепрозолу. Поверхневі епітеліоцити переважно мали типову для них у нормі будову. Частина головних клітин, цитоплазма яких заповнена великою кількістю зимогених гранул, містила невеликі за розмірами мітохондрії та фрагментовані канальці зернистої ендоплазматичної сітки. Інші головні клітини, які мали слизові гранули, були заповнені гіпертрофованими мітохондріями, АГ і паралельно розміщеними канальцями зернистої ендоплазматичної сітки, що свідчить про їх підвищену функціональну активність (рис. 3А). Для парієтальних клітин характерна гіперплазія канальців, тобто відбувалась активація секреції соляної кислоти. Водночас на фоні функціонально активних екзокриноцитів траплялись епітеліоцити 3 великим ядром і ядерцем, які притаманні для слизової оболонки щурів після введення омепрозолу й були ознакою анаплазії (до них можна віднести також наявність ядер із глибокими інвагінаціями, такі випинання каріолеми 3 ділянками каріоплазми в подальшому утворювали мікроядра). Серед ендокриноцитів переважали EcL та Ес клітини (рис. ЗБ), у цитоплазмі яких простежено специфічні гранули. Еухроматин у їхніх ядрах переважав над гетерохроматином. Також траплялася невелика кількість малодиференційованих ендокриноцитів, які через відсутність гранул ще не можна віднести до якогось типу. Крім того, спостерігали блукаючі глобулярні лейкоцити, здебільшого дегранульовані.

У кровоносних судинах простежено сладж-феномен. Крім того, переважно розширений просвіт був заповнений дрібнодисперсною електронно-щільною речовиною, яка є денатурованими білками плазми. Це свідчить про порушення реологічних властивостей крові. Ендотеліальні клітини, що вистилають ці мікросудини, - без суттєвих змін і мають ознаки білок-синтетичної активності. Мікроорганізмів у слизовій оболонці шлунка не виявлено.

Отже, уведення меланіну попереджувало розвиток диспластичних явищ в епітелії шлунка, що викликані гіпергастринемією. Парієтальні, головні епітеліоцити та мукоцити розміщувалися в один шар. Усі клітини мали виражені ознаки диференціювання.

У мукоцитах відзначено активацію біосинтетичних процесів: виражена гіперплазія гранулярної ендоплазматичної сітки, розширені цистерни апарату Гольджі, гранули муцину в апікальній поверхні клітин. Головні клітини містили розвинену гранулярну ендоплазматичну сітку, численні секреторні гранули зимогену в апікальній частині, які часто виділялися за апокриновим типом секреції, із ділянкою апікальної цитоплазми в просвіт залози. Парієтальні клітини містили глибокі мембранні канальці з багатьма мікроворсинками, активні мітохондрії із щільно розміщеними гіперплазованими кристами, що вказує на активацію їх кислотопродукуючої функції. Простежено велику кількість ендокринних епітеліоцитів. Серед них переважали ЕC-клітини, які вміщують серотонін, та D-клітини, які мали соматостатин. Тобто меланін стимулював ендокринну активність епітеліоцитів в епітелії шлунка. Водночас в епітеліальному шарі розміщувалися низькодиференційовані клітини зі світлою цитоплазмою, великою кількістю вільних рибосом і полісом, незначним умістом мітохондрій та активними великими ядрами. 

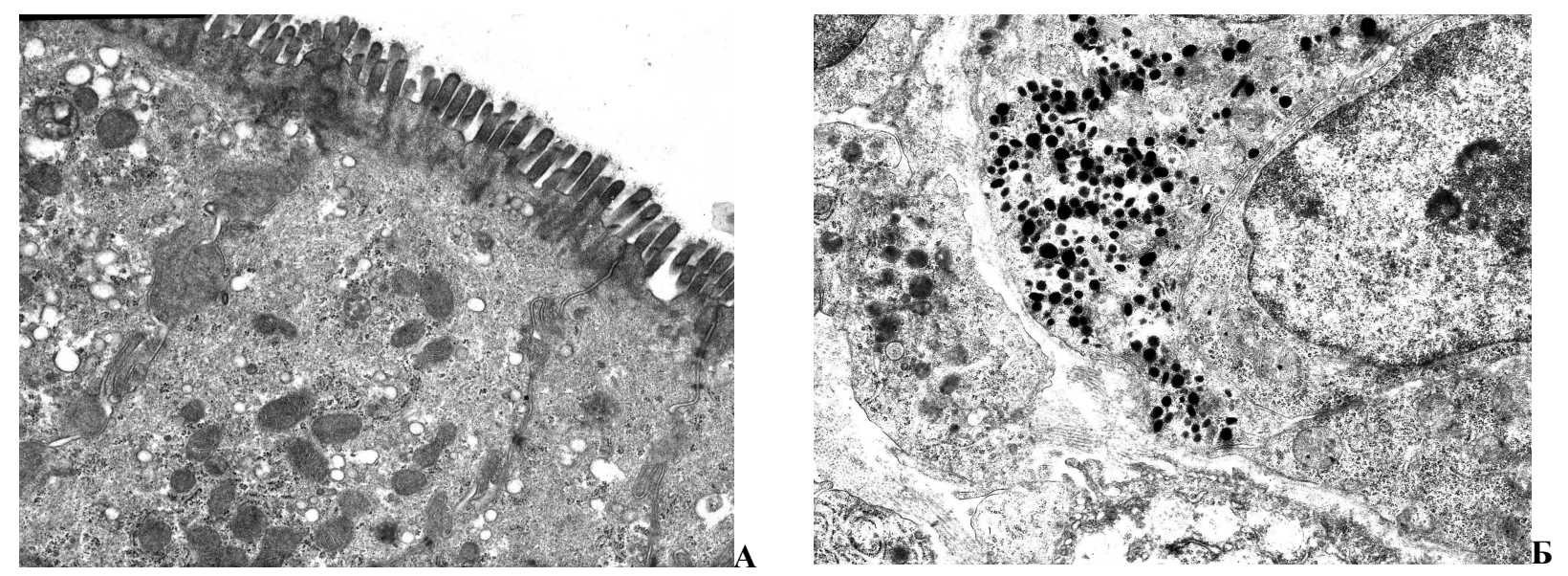

Рис. 3. Електронограма слизової оболонки шлунка після 28-денного введення омепразолу та меланіну. A: 36 X9600, Б: 36 X9000

Меланін - активатор біосинтетичних процесів у ядрі, регулятор процесів диференціювання клітин, потужний антиоксидант та цитопротектор, що здатний протидіяти карценогенезу $[10 ; 13 ; 20]$. Ця речовина спроможна попереджувати перекисне окислення мембран, стабілізуючи ї, чим можна пояснити відсутність гострих альтеративних процесів в епітеліальних клітинах шлунка [21]. Його стимуляційний вплив на експресію генетичного матеріалу стимулює процеси диференціювання епітеліоцитів, але не попереджує виникнення ознак їх атипії, які виникають під впливом омепразолу. Виражених ознак активації апоптичних процесів в епітеліоцитах шлунка не простежено.

Висновки та перспективи подальшого дослідження. Уведення природного пігменту меланіну упереджує малігнізацію слизової оболонки шлунка, викликаною тривалою гіпергастринемією, гальмуючи проліферацію та атипічне переродження епітеліальних клітин в слизовій оболонці шлунка.

Практичне значення роботи полягає в доведенні протипухлинної й протизапальної дії меланіну препарату природного походження - для подальшої рекомендації та впровадження для комплексної терапії й профілактики передракових станів шлунково-кишкового тракту.

\section{Джерела та література}

1. Закон України про захист тварин від жорстокого поводження // Відомості Верховної Ради України (BBP). - 2006. - № 27. -230 c.

2. Грищук В. Ультраструктурний аналіз клітин слизової оболонки фундального відділу шлунка щурів при гіпергастринемії / В. Грищук, О. К. Вороніна, М. Е. Дзержинський // Вісник Київського національного університету. - Біологія. - 2007. - № 49. - С. 13-15.

3. Жеребин Ю. А. Фармакологические свойства эномеланиновых пигментов / Ю. А. Жеребин // Доклады АН УССР. - 1984. - № 3. - С. 64-67.

4. Науково-практичні рекомендації з утримання лабораторних тварин та роботи з ними / Ю. М. Кожемякін, О. С. Хромов, М. А. Філоненко [та ін.]. - К. : Наук. думка, 2012. - 155 с.

5. Рак в Україні, 2014-2015 / 3. П. Федоренко [та ін.] // Бюл. Нац. канцер-реєстру України. - 2016. - № 17. C.16-20.

6. Регламентация экспериментов на животных - этика, законодательства, альтернативы / под ред. Н. А. Горбуновой. - М. : Знание, 2004. - 126 с.

7. Цирюк О. І. Вплив гіпергастринемії різної тривалості на структурно-функціональний стан слизової оболонки шлунка у щурів / О. І. Цирюк, О. К. Вороніна, Т. В. Овчарик // Механізми функціонування фізіологічних систем : зб. наук. пр. за матеріалами Міжнар. наук. конф., приуроченої до 60-річчя новоствореної каф. фізіології людини і тварин Львів. ун-ту ім. І. Франка. - Львів, 2006. - С. 152-153.

8. Цирюк О. І. Вплив омепразол-викликаної гіпергастринемії на базальну шлункову секрецію у щурів / О. І. Цирюк, Т. В. Берегова // Вісник проблем біології і медицини. - 2007. - Вип. 3. - С. 38-43.

9. Animal models to study the role of long-term hypergastrinemia in gastric carcinogenesis [Electronic resource] / R. Fossmark, G. Qvigstad, T. Martinsen [et al.] // Journal of Biomedicine and Biotechnology. - 2011. - Vol. 2011. Mode of access : http://dx.doi.org/10.1155/2011/975479

10. Anti-ulcerogenic effects of Nigella Sativa L. Melanin / A. El-Obeida [et al.] // World Journal of Pharmaceutical Research. - 2016. - Vol. 5, Issue 1. - P. 1579-1593. 
11. Effect of Blueberry Polyphenols on 3T3-F442A Preadipocyte Differentiation / S. S. Moghe [et al.] // Journal Of Medicinal Food. - 2012. - №15 (5). - P. 448-452.

12. Hypergastrinemia, type 1 gastric carcinoid tumors: diagnosis and management / O. Y. Hung, S. K. Maithel, F. F. Willingham [et al.] // J. Clin. Oncol. - 2011. - V. 29, № 25. - P. 713-715.

13. Green tea polyphenols provide photoprotection, increase microcirculation, and modulate skin properties of women / H. Ulrike [et al.] // The Journal of nutrition. - 2011. - № 141(6). - P.1202-1208.

14. Gurlenko T. The influence of long-term omeprazole-induced hypergastrinemia on water and electrolyte transport in the rat colon / T. Gurlenko, O. Voronina, V. Grishcuk [et al.] // Annales Universitatis Mariae Curie-Sklodowska. - 2006. - Vol. XIX, № 1, 10. - P. 71-73.

15. Inonotus obliquus Protects against Oxidative Stress-Induced Apoptosis and Premature Senescence / J. Seok Yun, J. Woon Pahk, J. Seok Lee [et al.] // Mol Cells. - 2011. - №31. - P. 423-429.

16. Kamon M. Green tea polyphenol(-)-epigallocatechin gallate suppressed the differentiation of murine osteoblast MC3T3-E1 cell / M. Kamon, R. Zhao, K. Sakamoto // Cell Biology International. - 2009. №34(1). - P. 109-116.

17. Mimura T. Studies on biological activities of melanin from marine animals. IV. Influence of squid melanin II on a high molecular glycoprotein level in rat gastric mucosa, and properties of peak I as a gastric mucosal defensive factor / T. Mimura, [et al.] // Chem Pharm Bull. - 1985. - № 33. - P. 2061-2068.

18. Molecular mechanism of black tea polyphenols induced apoptosis in human skin cancer cells: involvement of Bax translocation and mitochondria mediated death cascade / B. Halder [et al.] // Carcinogenesis. - 2008. № 29. - P. 129-138.

19. The gastric epithelial progenitor cell niche and differentiation of the zymogenic (chief) cell lineage / A. J. Bredemeyer [et al.] // Developmental Biology. - 2009. - Vol. 325, Issue 1. - P. 211-224

20. Slobodyanyk N. Pancreatic Enzymes Activity under the Conditions of Acute Stress and Melanin Administration Depending on the Stress Resistance / N. Slobodyanyk, T. Beregova, K. Neporada // Journal of Pharmacy and Pharmacology. - 2015. - № 3. - P. 232-236.

21. Watson R.R. Polyphenols in Human Health and Disease / R. R. Watson, V. R. Preedy, S. Zibadi // Academic Press, 2013. - P. 1360-1362.

Воронина Елена, Береговая Татьяна, Дзержинский Николай. Электронно-микроскопическое исследование слизистой оболочки фундального отдела желудка крыс при действии меланина на фоне гипергастринемии. С помощью электронно-микроскопического метода исследовались изменения в слизистой оболочке фундального отдела желудка крыс при действии меланина на фоне гипергастринемии. Исследования проводили на 30 самцах крыс. Материалом служили участки дна желудка: после 28-дневного введения омпепразола, после одновременного 28-дневного введения омперазола и меланина и контрольных животных. Показано, что при гипергастринемии во всех слоях слизистой происходят изменения, свидетельствующие о передракових процессах. В эпителии отмечается атипия клеток, разрушение их белок-синтезирующего аппарата, отсутствие дифференциации эндокриноцитов. Введение меланина нивелирует трофическое действие избыточного уровня гастрина на эпителиоциты слизистой оболочки желудка крыс, о чем свидетельствует появление дифференцированных эндокриноцитов, восстановление секреторной функции эпителиоцитов и отсутствие атипичных клеток.

Ключевые слова: гипергастринемия, слизистая оболочка желудка, малигнизация, меланин.

Voronina Olena, Beregova Tetyana, Dzerzhinsky Mykola. Ultrastructural Effects in Fundus Mucosa of Rats with Hypergastrinemia under the Influence of Exogenous Melanin. Using electron microscopy, ultrastructural changes in fundus mucosa of rats suffering from hypergastrinemia following melanin treatment were investigated. Studies were conducted using 30 male rats. Selected areas of stomach fundus were analyzed in rats which received: 28 days of single omeprazole injections, 28 days of combined omeprazole and melanin injections, and control animals. Hypergastrinemia induced ultrastructural changes were observed in all mucosal layers, indicating clear malignization. Atypic epithelial cells, destruction of their protein-synthesizing apparatus, lack of endocrine cells differentiation were found. Introduction of melanin was shown to eliminate the trophic effect of excessive gastrin levels to the epithelial cells of gastric mucosa in rats, as evidenced by the appearance of differentiated endocrine cells, restoration of secretory function of epithelial cells and lack of atypical cells.

Key worlds: hypergastrinemia, fundus mucosa of stomach, malignization, melanin.

Стаття надійшла до редколегії 22.09.2016 р. 